\title{
POLA PERKEMBANGAN PERUMAHAN DI KOTA SURAKARTA
}

\section{PATTERNS OF HOUSING DEVELOPMENT IN SURAKARTA CITY}

\author{
W. Widodo', S. Sunarti ${ }^{2}$ \\ ${ }^{1}$ Satker BP2BT; Kementrian Pekerjaan Umum dan Perumahan Rakyat; cpjwidodo@gmail.com \\ 2Departemen Perencanaan Wilayah dan Kota; Universitas Diponegoro, Kota Semarang, Jawa Tengah; n4rtio8@gmail.com
}

Info Artikel:

- Artikel Masuk: 7 Februari 2019

\begin{abstract}
ABSTRAK
Sektor perkembanagan perumahan di Kota Surakarta mengalami perkembangan yang sangat pesat. Pertumbuhan penduduk baik alami maupun migrasi yang pesat membuat kebutuhan akan lahan di perkotaan semakin menjadi tantangan serius. Seperti halnya Kota Surakarta dengan lokasi strategis menjadi pusat kota dari daerah di sekitarnya menjadikan pertumbuhan Kota Surakarta menjadi pesat. Tak terkecuali kebutuhan perumahan mengalami perkembangan yang signifikan dari banyaknya permintaan masyarakat yang tinggal di Kota Surakarta. Tujuan dari penelitian ini adalah menidentifikasi pola perkembangan perumahan untuk melihat kebutuhan sarana prasarana dan utilitas di Kota Surakarta. Studi ini menggunakan metode kuantitatif untuk menggambarkan perkembangan pertumbuhan perumahan terkait pola sebaran di Kota Surakarta. Menggunakan data sekunder yang diperoleh dari inventaris Kota Surakarta dan data primer melalui observasi serta wawancara dengan instansi terkait. Mengadopsi analisis tetangga terdekat (nearest neighborhood) untuk mengetahui pola sebaran perumahan. Hasil dari temuan 4 analisis ini adalah pola perkembangan perumahan yang mengelompok dengan arah kosentrasi di pinggiran kota mengikuti jalan, kepadatan yang rendah serta harga lahan yang relatif terjangkau bagi masyarakat.
\end{abstract}

Kata Kunci : pola persebaran; perumahan developer

\begin{abstract}
The housing development sector in Surakarta City has experienced very rapid development. Population growth, both natural and rapid migration, makes the need for land in urban areas increasingly a serious challenge. As with the city of Surakarta, with its strategic location being the city center of the surrounding area, the growth of Surakarta City has become rapid. No exception to housing needs experienced a significant development from the large demand of people living in Surakarta City. The purpose of this study is to identify patterns of distribution of housing to see the needs of infrastructure and utilities in Surakarta City. This study uses quantitative methods to describe the development of housing growth related to the distribution pattern in Surakarta City. Using secondary data obtained from Surakarta City inventory and primary data through observation and interviews with relevant agencies. Adopting the analysis of the nearest neighbor (nearest neighborhood) to find out the pattern of distribution of housing. The results of the findings of this analysis are that the pattern of housing distribution clustered with the direction of concentration on the edge of the city following the road, low density and relatively affordable land prices for the community.
\end{abstract}

Keywords: distribution patterns; housing developer

Copyright $\odot 2016$ GJGP-UNDIP

\section{PENDAHULUAN}

Pertumbuhan dan perkembangan kota dianggap sebagai masalah global, hal ini disebabkan pertumbuhan populasi penduduk di perkotaan semakin tinggi (Fuseini \& Kemp, 2016). Kota adalah wilayah dengan sumber daya yang tersedia dalam jumlah sangat besar. Selain itu, pertumbuhan ekonomi melesat 
cepat, pekerjaan dan berbagai layanan disediakan. Peningkatan yang cepat dan pertumbuhan populasi yang besar perkotaan menyebabkan krisis rumah yang akan berdampak pada pemenuhan kebutuhan rumah bagi masyarakat (Sunarti, Yuliastuti dan Indriastjario, 2018). Pertumbuhan kota yang cepat, yang dihasilkan dari ekspansi cepat di inti kota dan munculnya urban sprawl dari tahun 1970-an dan 1980-an telah menyebabkan banyak masalah dan tantangan di kota-kota (Mirkatouli, Samadi dan Hosseini, 2018). Salah satu masalah paling penting di kota adalah kelangkaan lahan perkotaan yang telah membuat lahan menjadi salah satu persyaratan terpenting untuk penentuan lokasi perumahan.

Seiring dengan perjalanan waktu, kota mengalami perkembangan sebagai akibat dari pertumbuhan penduduk, perubahan sosial, ekonomi dan budaya serta interaksinya dengan kota-kota lain di daerah sekitarnya (Setioko, 2013) Secara fisik perkembangan suatu kota dapat dilihat dari penduduknya yang makin bertambah dan makin padat, bangunan-bangunan yang semakin rapat dan wilayah terbangun terutama permukiman yang cenderung semakin luas, serta semakin lengkapnya fasilitas kota yang mendukung kegiatan sosial dan ekonomi kota. Menurut (Bintaro Dalam Koestoer, 2001), permukiman menempati areal paling luas dalam penataan ruang, mengalami perkembangan yang selaras dengan perkembangan penduduk, dan mempunyai pola-pola tertentu yang menciptakan bentuk dan struktur suatu kota yang berbeda dengan kota lainnya. Perkembangan permukiman pada bagian-bagian kota tidaklah sama, tergantung pada karakteristik kehidupan masyarakat, potensial sumber daya yang tersedia, kondisi fisik alami serta fasilitas kota yang terutama berkaitan dengan transportasi.

Sebagai wilayah yang mayoritas bersifat kontinental, kota-kota di Pulau Jawa tidak lepas dari fenomena interaksi yang mudah dalam rangka memenuhi kebutuhan masing-masing. Hal ini disebabkan karena kota dalam perspektif sistem kota-kota memiliki keterkaitan dan saling berhubungan satu dengan yang lainnya (Adisasmita, 2015). Kota Surakarta sebagai pusat pemerintahan yang juga pusat ekonomi mengalami perkembangan yang sangat pesat dalam laju pertumbuhan penduduk. Pertumbuhan penduduk ini akibat meningkatnya urbanisasi maupun pertumbuhan secara alami. Dalam kurun 10 tahun terakhir pertumbuhan perumahan di pinggiran kota Surakarta menunjukkan peningkatan yang tajam. Pertumbuhan yang cepat cenderung tidak terkendali dan terarah, khususnya terkait sebaran lokasi perumahan dan permukiman.

Salah satu akibat yang ditimbulkan oleh pesatnya pembangunan perumahan adalah gangguan terhadap ekosistem, yang mengakibatkan berkurangnya daerah resapan air di Surakarta yang harus dilindungi. Dari permasalahan yang sudah ditemukan, penulis mencoba mengkaji pola sebaran perumahan di Kota Surkarta. Selain itu permasalahan loncatan-loncatan peruntukan lahan perumahan / urban sprawl (Giyarsih, 2015) fenomena ini sangat berpengaruh pada pola jaringan, yang akhirnya menimbulkan masalahmasalah tansportasi, akibat lain yang ditimbulkan adalah inefisensi lahan dan biaya yang dampaknya sangat besar sehingga sulit dilakukan penataan kembali. Berdasarkan permasalahan diatas maka pertanyaan penelitiannya adalah Bagaimana Pola perkembangan perumahan di Kota Surakarta?

Penelitian ini merumuskan dan mengukur pola sebaran perumahan dalam lingkup fisik. Untuk faktor non fisik sosial - budaya, politik dan ekonomi akan dimasukkan sebagai faktor yang mempengaruhi pertumbuhan perumahan. Faktor kebijakan terhadap perumahan baik dari segi kelembagaan maupun dari segi kebijakan bidang perumahan dan permukiman yang berpihak kepada seluruh masyarakat. Faktor ekonomi menyangkut nilai bisnis pembangunan perumahan yang cukup tinggi. Faktor sosial-budaya terkait dengan proses interaksi masyarakat di dalam suatu kawasan perumahan dan permukiman yang perlu pembinaan. Penelitian ini hanya membahas perumahan yang dibangun developer dan pemerintah dalam lingkup penelitiannya.

Perencanaan kota juga seharusnya diawali dengan penelitian yang cukup mendalam tentang kawasan tersebut mengenai lingkungan fisikn serta manusianya dan bukan karena dikejar waktu dan penghabisan dana anggaran. Menurut Cliff Moughtin (1992) juga mengungkapkan bahwa dasar dari perancangan kota adalah pembangunan yang berkelanjutan yang tidak merusak lingkungan dan memberi kontribusi pada peningkatan ekonomi dan sosial masyarakatnya.

Studi yang pernah dilakukan adalah pola persebaran permukiman, secara umum merupakan susunan sifat persebaran permukiman dan sifat hubungan antara faktor-faktor yang menentukan terjadinya sifat 
perkembangan permukiman tersebut. Menurut Hagget (1975) pola persebaran permukiman ada 3 tipe pola yaitu seragam (uniform), acak (random), mengelompok (clustered). Dalam menilai pola sebaran perumahan ini analisis yang di pakai adalah analisis tetangga terdekat (nearest neighborhood) dengan melihat kedekatan jarak antara perumahan dengan perumahan yang lainnya (kedekatan aksesibilitas) serta luas wilayah Kota Surakarta. Menurut Branch dalam Yoelianto (2005) mengemukakan bahwa pada skala yang lebih luas, bentuk kota secara keseluruhan mencerminkan posisinya secara geografis dan karakteristik tempatnya. Berdasarkan teori ini, dapat diartikan bahwa perkembangan suatu kota dapat ditentukan oleh posisi geografis serta karakteristik tempat dimana suatu proses kegiatan berlangsung sehingga dapat membentuk pola- pola yang mengikuti kondisi wilayah tersebut. Pola-pola perkembangan kota di atas tanah datar digambarkan secara skematik oleh Branch antara lain ialah radial menerus, radial tidak menerus, grid iron menerus, radial konsentris menerus dan linier menerus. Studi ini mengindifikasikan dan menganalisis tidak hanya tentang kebijakan namun proses dalam penentuan pola sebaran perumahan di Kota Surakata juga menggunakan variabel sosial, ekonomi, serta fisik terutama sarana prasarana yang mempengaruhi pola persebaran perumahan yang dibangun oleh swasta/developer.

\section{DATA DAN METODE}

\subsection{Data Penelitian}

Kota Surakarta merupakan salah satu kota besar yang ada di Provinsi Jawa Tengah, menjadi pusat perdagangan dan jasa untuk daerah kabupaten yang ada di sekitarnya atau yang sering di sebut sebagai kawasan Subosukawonosraten sekaligus menjadi batas administrasi Kota Surkakarta. Kota Surakarta memiliki lahan yang cukup datar yaitu 3.537 ha atau $80,3 \%$ berupa lahan dengan kemiringan $0-2 \%$, sedangkan sisanya 866 ha atau 19,7\% berupa lahan bergelombang dengan kemiringan 2-15\%.

Dari luas Kota Surakarta kurang lebih $44.04 \mathrm{~km}^{2}$ sebagian besar lahan digunakan untuk permukiman sebesar $28.85 \mathrm{ha}^{2}(61,69 \%)$, lahan kosong $5.3 \mathrm{ha}^{2}(1,20 \%)$, kemudian jasa sebesar $3.91 \mathrm{ha}^{2}(9,71 \%)$ dan lainlainnya sebesar $3.42 \mathrm{ha}^{2}$ (9,07\%). Jumlah penduduk Kota Surakarta pada tahun 2018, mencapai 515.372 jiwa, denan tingkat kepadatan $11.718,78 \mathrm{jiwa} / \mathrm{km}^{2}$. Penduduk menurut mata pencaharian, mayoritas penduduk Kota Surakarta berprofesi sebagai jasa, mahasiswa, pengusaha/perdagangan, dan PNS/ABRI/polri. Secara fisik, dari aspek sumber daya (sumber daya alam, dalam arti lokasi), posisi Kota Surakarta berada pada jalur strategis yaitu pertemuan jalur kendaraan antara Semarang dengan Yogjakarta (Joglo Semar), dan jalur Surabaya dengan Yogjakarta. Dengan posisi yang strategis ini maka tidak heran Kota Surakarta menjadi pusat pertumbuhan properti yang sangat pesat dalam kurun beberapa tahun ini (Soeratno, 2015). kekuatan ekonomi konsumen, khususnya dengan kemampuan daya beli konsumen. Jumlah terbesar berada di kecamatan Banjarsari dan Jebres, masing-masing sebesar 34,508 dan 31,011. Penelitian ini hanya mengambu sampel perumahan yang dibangun oleh developer dan pemerintah dengan jumlah totoal yaitu 70 perumahan yang berada di Kota Surakarta .

\subsection{Metode Penelitian}

Penelitian ini menggunakan alat metode kuantitatif dalam prosesnya, meliputi identifikasi kebutuhan data primer maupun sekunder yang dapat dijelaskan dibawah ini :

1. Pengumpulan data primer dilakukan dengan melalui observasi lokasi dan wawancara kepada pemerintah setempat perihlal pola sebaran perumahan di Kota Surakarta.

2. Pengumpulan data sekunder di perleh melalui inventaris data umum wilayah studi, kajian struktur tata ruang Kota Surakarta dan data lain yang dianggap penting berkaitan permaslahan yang diteliti.

Pendekatan yag di pakai dalam penulisan ini adalah menggunakan pendekatan metode kuantitatif, dengan mengadopsi rumus (Hagget, 1975) analisis tetangga terdekat (nearest neigborhood analysis). Lebih jelasnya jenis analisis data yang digunakan dalam penelitian ini, dijelaskan sebagai berikut:

Analisis sebaran lokasi perumahan

Penelitian ini mencoba mengaitkan pola sebaran perumahan di Kota Surakarta dengan neraest neighbourhood analysis. analisis ini digunakan untuk menentukan apakah pola sebaran perumahan di Kota 
Surakarta membentuk pola random, mengelompok atau seragam dengan melihat nilai T. Nilai T/indeks penyebaran tetangga terdekat sendiri diperoleh melalui formula :

$$
\begin{array}{cl}
\qquad & \mathrm{T}=\frac{j \mathrm{u}}{j h} \\
\text { Keterangan } & : \\
\mathrm{T} & : \text { Indeks Penyebaran tetangga terdekat } \\
\mathrm{Ju} & : \text { Jarak rata-rata yang diukur antara titik dengan titik tetangga terdekat } \\
\mathrm{Jh} & : \text { Jarak rata-rata yang diperoleh andaikata semua titik mempunyai pola random }
\end{array}
$$

Dari nilai T, selanjutnya dapat diintrepretasikan dengan continum nearest neighbour analisis, sebagai berikut :

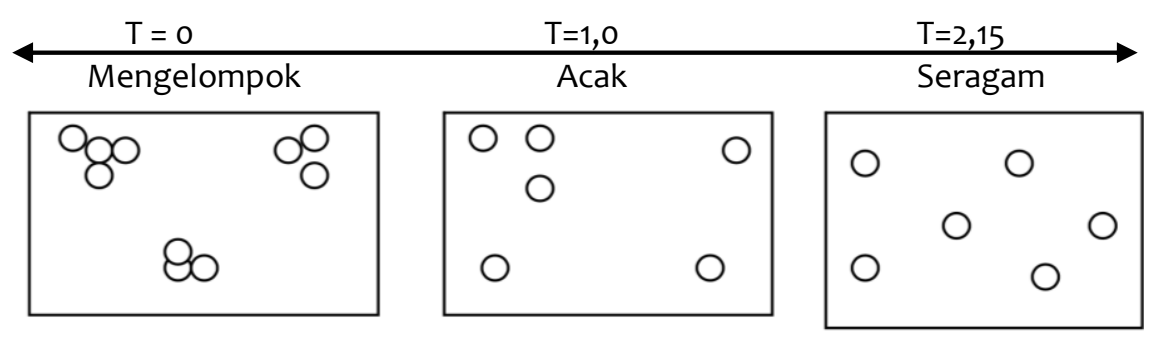

Sumber: Hagget, 1975

Gambar 1. Countinum Nearest Neighbour Analyisis

\section{HASIL}

Arahan lokasi perumahan seluas 2.274,65 Ha tersebar di 5 Kecamatan Kota Surakarta. Dalam penyediaannya, baik perseorangan maupun melalui pihak pengembang. Mengacu dalam RPJPD Kota Surakarta tahun 2005-2025, dengan jelas tersirat garis kebijakan pembangunan yang diarahkan untuk meningkatkan perkembangan dan peningkatan pembangunan di kawasan Surakarta bagian utara, yaitu kawasan utara relatif tertinggal perkembangan pembangunannya dibandingkan dengan kawasan selatan. Satu sisi di kawasan selatan sudah tidak tersedia ruang yang cukup dan memiliki tingkat kepadatan penduduk tertinggi di Kota Surakarta.

Secara garis besar terjadinya pola permukiman menurut Wahyu dan Moch (2014) dan dipengaruhi oleh faktor fisik baik alam maupun buatan, faktor sosial-ekonomi, dan faktor budaya manusia atau penduduk. Faktor-faktor pengaruh tersebut diterapkan dalam analisis pola sebaran perumahan terhadap aspek fisik, kebijakan, sosial-budaya dan ekonomi. Penjelasan lebih detail terkait 4 analisis tersebut dapat dijelaskan pada sub pokok dibawah ini.

\subsection{Analisis Pola Sebaran Perumahan Terhadap Aspek Kebijakan}

Aspek kebijakan sangat mempengaruhi dalam terbentuknya pola sebaran perumahan di Kota Surakarta dalam hal ini dilihat dari kesesuaian lahan yang di spasialkan memperlihatkan perumahan yang tersebar di kelima kecamatan Kota Surakarta. Indikator yang dipakai dalam analisis sebaran perumahan terhadap aspek kebijakan yaitu sawah irigasi, cagar budaya, garis sempadan sungai dan jalur kereta api, fasos \& fasum, ruang terbuka hijau, titik TPS \& TPA, lahan makam dan lapangan. Seperti yang dikemukakan oleh (Jayadinata, 1999) bahwa tata guna lahan perkotaan menunjukkan pembagian dalam ruang dan peran kota. Misalnya dalam kawasan perumahan pemanfaatan lahan untuk fasilitas pelayanan kota cenderung mendekati akses barang dan orang sehingga dekat dengan jaringan transportasi serta dapat dijangkau dari kawasan permukiman dan tempat berkerja serta fasilitas pendidikan (Chapin, 1995). Dalam analisis ini melihat setiap penggunaan lahan pada setiap titik perumahan dikaitkan dengan kebijakan yang dibuat oleh pemerintah dalam menentukan pembangunan perumahan di Kota Surakarta. Dibawah ini adalah gambar 2 analisis sebaran perumahan terhadap kebijakan tata guna lahan. 
Widodo, Sunarti/ Jurnal Pembangunan Wilayah dan Kota, Vol.15 No.4, 2019, 288-300 Doi: https://doi.org/10.14710/pwk.v15i4.21984

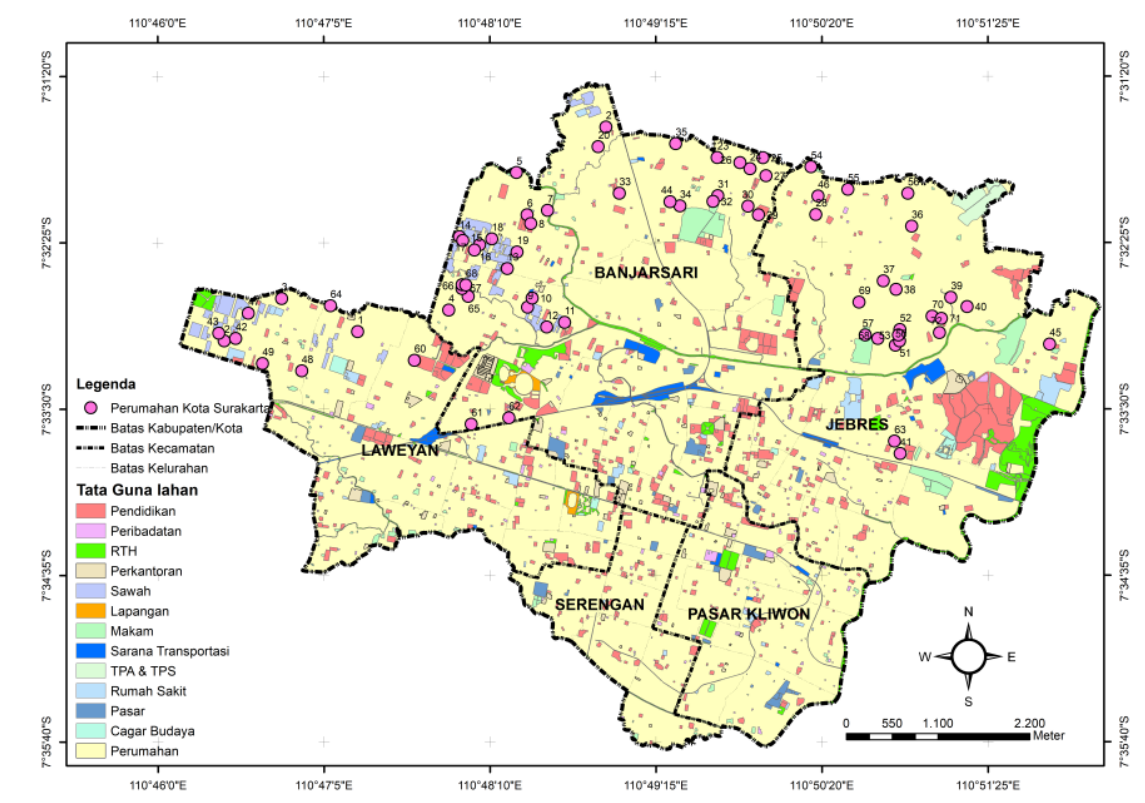

Sumber: Analisis, 2018

Gambar 2. Sebaran Perumahan Terhadap Tata Guna Lahan

Dari gambar 2 menunjukkan bahwa analisis terhadap penggunaan lahan diperuntukkan untuk perumahan sebagian sudah di dalam zona untuk permukiman, akan tetapi beberapa perumahan masih menempati areal sawah dan sempadan sungai. Perumahan bagian areal kawasan barat (Kecamatan Laweyan) cenderung menempati di sawah non teknis sementara kawasan bagian utara (Kecamatan Banjarsari dan Kecamatan Jebres) kebanyakan menempati di lahan tegalan dan lahan sawah non teknis. Seperti yang ditunjukkan dalam titik - titik analisis perumahan sebagian menempati dalam area konversi lahan yang sebagian besar terletak pada Kelurahan Karangasem (Kecamatan Laweyan), Kelurahan Banyuanyar dan Kelurahan Sumber (Kecamatan Banjarsari). Sementara titik perumahan yang menempati areal lahan kosong dan tegalan dominan di Kelurahan Kadipiro (Kecamatan Banjarsari) dan Kelurahan Mojosongo (Kecamatan Jebres). Pola sebaran pada analisis ini menunjukkan bahwa lahan kosong dan lahan tegalan menjadi alasan paling kuat dalam menentukan kebijakan pemilihan lokasi perumahan di Kota Surakarta. Menurut Chapin (1995) keterjangkauan antara fasilitas umum dan kemudahan bertransportasi menjadi tolak ukur dalam membangun kawasan perumahan. Dari hasil rangkuman analisis ini dapat disimpulkan bahwa kebijakan hanya berlandaskan pada lahan kosong tanpa memperhatikan fasilitas umum.

\subsection{Analisis Pola Sebaran Perumahan Terhadap Aspek Sosial Budaya}

Dari identifikasi yang dispasialkan dari aspek sosial budaya pengaruh sebaran perumahan terhadap demografi dapat memperjelas justifikasi dari setiap pola sebaran yang terbentuk. Menurut Tukiran (2002) faktor yang menyebabkan seseorang melakukan mobilitas kependudukan diantaranya faktor sosial, ekonomi dan budaya. Adapun macam mobilitas terbagi menjadi dua garis besar yaitu mobilitas penduduk tidak permanen dan permanen (migrasi). Penduduk kota Surakarta tersebar pada 5 kecamatan mempunyai total jumlah penduduk 516.102 jiwa (2017) dengan kepadatan 11.718,78. Kecamatan Banjarsari memiliki jumlah penduduk yang paling besar akan tetapi tingkat kepadatan yang rendah karena mempunyai daerahnya cukup luas, sementara Kecamatan Serengan memiliki jumlah penduduk paling rendah tetapi dengan kepadatan yang paling tinggi diantara kecamatan lain karena mempunyai daerah yang kecil. Gambaran sederhana ini mengindikasikan bahwa pembangunan perumahan tidak mungkin lagi dilakukan di daerah bagian selatan yaitu Kecamatan Serengan dan Kecamatan Pasar Kliwon yang mempunyai kepadatan yang tinggi sedangkan bagian utara lebih cenderung cocok untuk pembangunan perumahan karena masih tergolong dengan kepadatan yang rendah yaitu terletak di Kecamatan Banjarsari dan Kecamatan Jebres. 
Analisis sebaran perumahan terhadap demografi ini menggunakan indikator kepadatan penduduk di Kota Surakarta untuk mengidentifikasi pola sebarannya. Untuk lebih detailnya di bawah ini adalah gambar 3 analisis pola sebaran terhadap demografi.

umber: Analisis, 2018

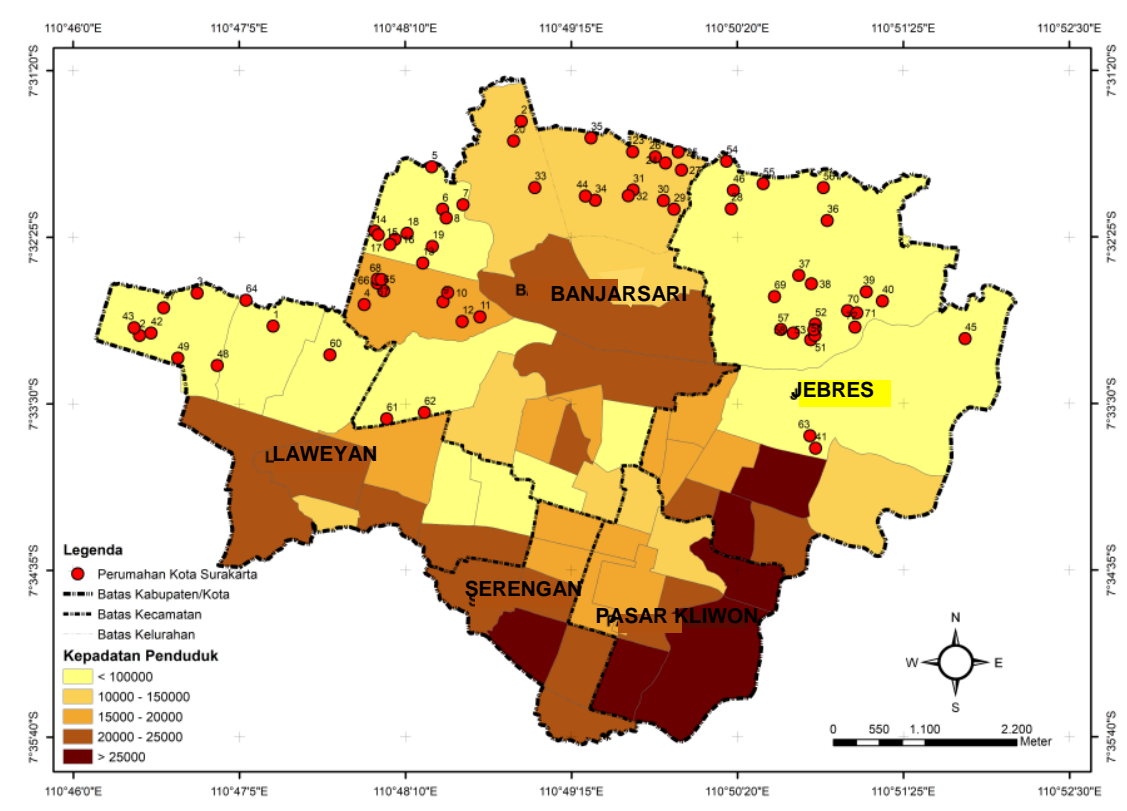

Gambar 3. Sebaran Perumahan Terhadap Demografi (Analisis, 2018)

Dari Gambar 3 analisis sebaran perumahan terhadap demografi dapat dijastifikasikan titik lokasi penelitian cenderung dengan tingkat kepadatan penduduk yang sedang. Pada Kecamatan Banjarsari terdapat 2 variasi dalam titik penelitian yaitu kepadatan rendah dan sedang. Sedangkan pada Kecamatan Pasar Kliwon terjadi 3 variatif kepadatan penduduk dari kepadatan rendah, sedang dan tinggi, hal ini menunjukkan aktivitas yang sangat bervariatif dalam satu kecamatan. Hal ini dipengaruhi oleh aspek sejarah dari keberadaan pusat perekonomian dan pusat pemerintahan di masa kerajaan Pakubuwono yang menjadi cikal bakal pertumbuhan perumahan di Kota Surakarta. Dapat dilihat dari tingkat kepadatan tinggi di Kecamatan Serengan juga dipengaruhi oleh keberadan permukiman yang berada pada pusat kebudayaan yaitu Pura Mangkunegaran. Dari kepadatan yang tinggi di bagian selatan Kota Surakarta mempengaruhi persebaran perumahan yang mengarah pada pinggiran kota Surakarta (Kelurahan Mojosongo dan Kelurahan Banyuanyar) yang masih mempunyai kepadatan yang rendah. Hasil dari rangkuman ini bahwa pergerakan persebaran perumahan beranjak dari kepadatan tinggi yang berada di pusat aktivitas kota mengarah kepinggiran kota dengan kepadatan yang rendah. Hal ini juga mengkorfirmasi teori Tukiran (2002) bahwa mobilitas pergerakan masyarkat dipengaruhi oleh faktor sosial budaya yaitu pergerakan masyarakat yang dipengaruhi oleh kepadatan yang tinggi di pusat kebudayaan atau pusat aktifitas kota kemudian menyebar ke pinggiran kota.

\subsection{Analisis Pola Sebaran Perumahan Terhadap Aspek Ekonomi}

Terbentuknya perumahan menurut Deurloo dan Musterd (2001) terdapat 4 faktor salah satunya adalah proses restrukturisasi ekonomi (the economic restructuring process), proses pertumbuhan atau perbaikan perekonomian baru di suatu kawasan. Analisis ini menggunakan indikator sebaran penduduk miskin, yang mencerminkan kekuatan sosial ekonomi penghuni perumahan.

Proses dalam aspek sosial ekonomi ini mempengaruhi pola sebaran perumahan di Kota Surakarta. Dalam analisis ini pola perumahan cenderung mengelompok dengan status ekonomi menengah ke bawah 
(Kecamatan Laweyan, Kecamatan Banjarsari dan Kecamatan Jebres). Hal ini didasari oleh kebijakan pemerintah yang mengarahkan pembangunan rumah sederhana dan sangat sederhana di bagian utara untuk mencukupi akan penyediaan akan permintaan perumahan yang tiap tahun semakin naik (Yuuwono, 2007). Di bawah ini adalah gambar 4 analisis sebaran perumahan terhadap aspek ekonomi.

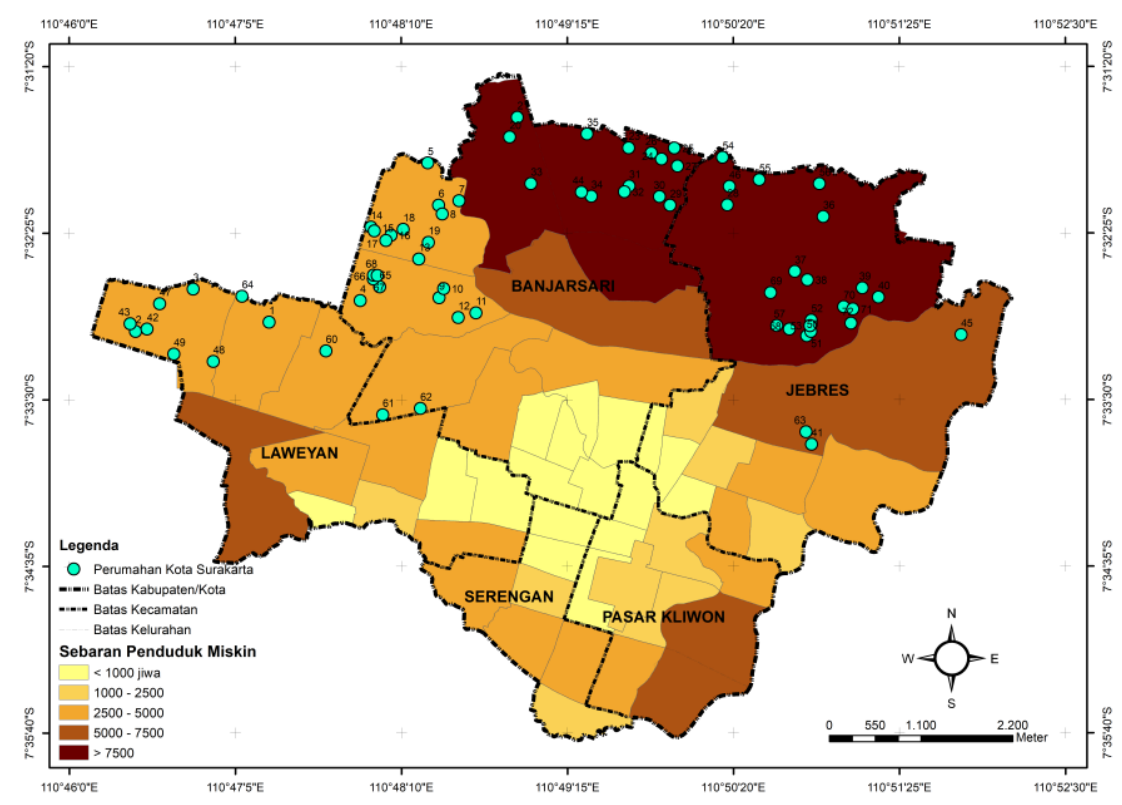

Sumber: Analisis, 2018

\section{Gambar 4. Sebaran Perumahan Terhadap Ekonomi}

Dari gambar 4 menunjukkan bahwa sebaran perumahan cenderung berlokasi di daerah dengan kondisi sosial ekonomi yang cenderung kurang stabil (ekonomi menegah - ke bawah). Indikator aspek ekonomi terlihat dari daya beli masyarakat, yang terpresentasi dari besarnya harga rumah. Dari peta sebaran penduduk berpenghasilan rendah dapat menjadi indikator tingkat daya beli masyarakat untuk mempunyai perumahan di kota Surakarta, dengan daerah dengan sebaran penduduk miskin yang besar menunjukkan kondisi ekonomi yang relatif kurang stabil dapat dilihat dari 2 kecamatan yaitu Kecamatan Jebres dan sebagian Kecamatan Banjarsari. Hal ini terkait dengan sebaran fasilitas umum yang jauh dari pusat kota menjadikan nilai lahan masih terjangkau oleh masyarakat menegah - ke bawah. Sementara perumahan yang berada pada di Kecamatan Laweyan dan sebagian Kecamatan Banjarsari termasuk dalam kondisi ekonomi yang stabil, yaitu banyak kondisi perumahan yang mempunyai fisik yang bagus dan dekat dengan fasilitas publik seperti pasar, pusat perbelanjaan, sarana pendidikan dan kesehatan serta aksesibilitas ke jalan raya yang cukup dekat membuat nilai harga perumahan tinggi. Persebaran perumahan cenderung mengarah ke arah utara, jika dilihat dari perspektif aspek ekonomi hal tersebut disebabkan oleh ialah masih terjangkaunya harga rumah dibanding dengan wilayah lain di Kota Surakarta.

\subsection{Analisis Pola Sebaran Perumahan Terhadap Aspek Fisik}

Aspek fisik menjadi salah satu struktural yang sangat penting bagi pertumbuhan suatu kawasan seperti halnya perumahan di Kota Surakarta. Kajian teori yang di uraikan oleh Singh (2015) mengatakan bahwa faktor pembentukan perumahan dan permukiman dipengaruhi oleh beberapa aspek yaitu faktor fisik dilihat dari sarana dan prasarananya serta utilitas pendukungnya. Analisis pola sebaran perumahan terhadap aspek fisik ini dapat menjastifikasi ke mana arah dan pola sebaran perumahan di Kota Surakarta dengan beberapa indikator fasilitas dan utilitas di Kota Surakarta. Persebaran fasilitas dan utilitas mestinya menjadi barometer tumbuhnya kawasan baru seperti perumahan. 
Sarana prasarana terkait dengan kemudahan dan pelengkap yang diperuntukkan untuk masyarakat dalam menjalani aktivitas (Chapin, 1995). Aktivitas yang beragama membentuk keberagaman pola fasilitas umum antara satu wilayah dengan wilayah lainnya (Miro, 2005). Seperti keberagaman pola pengaturan fasilitas umum terjadi akibat berpencarnya lokasi fasilitas umum secara geografis dan berbeda jenis serta intensitas kegiatannya. Kondisi ini membuat penyebaran lahan dalam suatu wilayah menjadi tidak merata.

Sarana prasarana juga bisa diartikan alat untuk kehidupan bermasyarakat yang lebih baik. Untuk mencapai analisis sebaran perumahan terhadap sarana dan prasarana ini menggunakan alat webgis (overlay union) dengan beberapa indikator yakni : Fasum (titik TPS \& TPA, halte, terminal, stasiun) dan Fasos (sarana peribadatan, sarana pendidikan, sarana kesehatan, pasar, supermarket, makam). Analisis ini melihat jangkauan dari setiap titik perumahan ke sarana dan prasarana Kota Surakarta sebagai pengaruh pembentuk pola sebaran. Dalam analisis ini mengukur keterjangkauan jarak antara titik perumahan dengan sarana prasarana untuk mencapainya. Jika dilihat sekilas tampak dari gambar analisis terhadap sarana prasarana cenderung menjauh dengan fasilitas kota, fasilitas umum hanya terpusat di inti kota. Di bawah ini adalah gambar 5 analisis sebaran perumahan terhadap sarana prasarana kota Suraka

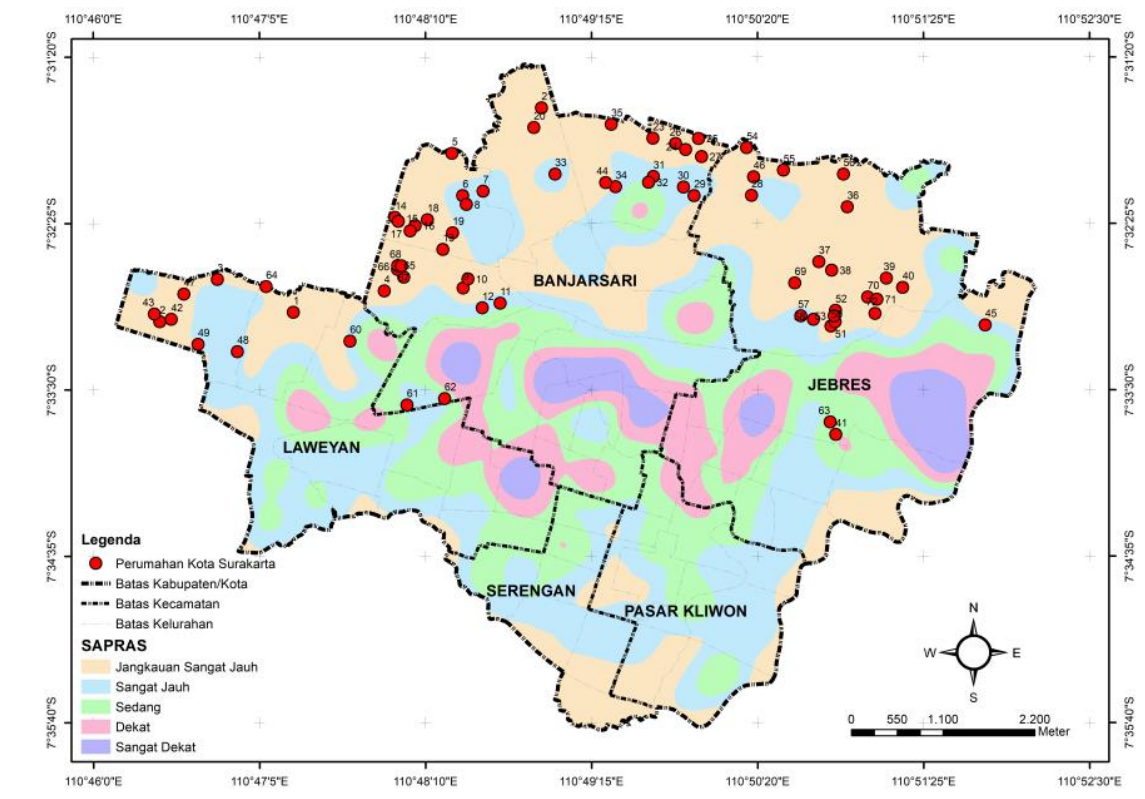

Sumber: Analisis, 2018

Gambar 5. Sebaran Perumahan Terhadap Sarana Prasarana

Dari gambar 5 tentang sebaran perumahan terhadap aspek sarana prasarana terlihat fasilitas di pusat kota sangat terpenuhi dan tingkat keterjangkauanya sangat dekat dibanding dengan wilayah di bagian barat dan utara, yang dimana dominan menjadi lokasi penelitian. Data ini menunjukkan bahwa persebaran perumahan yang dibangun developer dan pemerintah masih banyak yang belum terjangkau oleh fasilitas umum. Fasilitas yang disediakan pemerintah belum tersebar di setiap wilayah kota Surakarta, hanya terfokus pada satu titik di pusat kota. Pada perumahan wilayah bagian barat (Kecamatan Laweyan) dapat dilihat ada beberapa perumahan yang dalam jangkauanya masih belum terpenuhi akan fasilitas publik, akan tetapi pada kawasan ini masih dalam tahap aksesibilitas transportasi yang cukup mendukung untuk menjangkau fasilitas publik. Sedangkan perumahan wilayah bagian utara (Kecamatan Banjarsari) dari hasil analisis spasial menunjukkan pola sebaran perumahan akan sarana prasarana juga belum terpenuhi. Begitu juga di wilayah bagian timur (Kecamatan Jebres) masih banyak juga pola sebaran perumahan yang masih jauh akan keterjangkauan fasilitas umum. Analisis ini dapat ditarik kesimpulan bahwa sarana prasarana yang belum merata dan hanya terpusat di tengah Kota Surakarta. Sedangkan dari kebijakan yang diarahkan ke wilayah utara sebagai pertumbuhan baru cenderung masih minim oleh sarana prasarana yang tersedia untuk pembangunan perumahan. Pengaruh dari pola sebaran perumahan pada titik lokasi penelitian tidak ada 
Widodo, Sunarti/ Jurnal Pembangunan Wilayah dan Kota, Vol.15 No.4, 2019, 288-300 Doi: https://doi.org/10.14710/pwk.v15i4.21984

kaitanya terhadap tersedianya sarana prasarana yang layak, akan tetapi cenderung pada pemenuhan jalur jalan saja.

Utilitas menjadi salah satu faktor fisik yang wajib diterapkan pada setiap permukiman (Singh et al., 2005). Dalam analisis ini menggunakan beberapa indikator dalam menentukan analisis sebaran perumahan terhadap utilitas antara lain : jaringan limbah, jaringan drainase, jaringan telephone, jaringan air bersih dan jaringan gas rumah tangga. Dengan melihat terpenuhinya jaringan utilitas setiap titik perumahan di Kota Surakarta. Seperti halnya analisis sebaran perumahan terhadap sarana prasarana pemenuhan akan utilias pada titik penelitian perumahan di wilayah pinggiran Kota Surakarta masih belum merata khususnya perumahan yang berada pada Kelurahan Mojosongo (Kecamatan Jebres). Analisis tentang sebaran perumahan terhadap utilitas dapat dilihat gambar 6 di bawah ini.

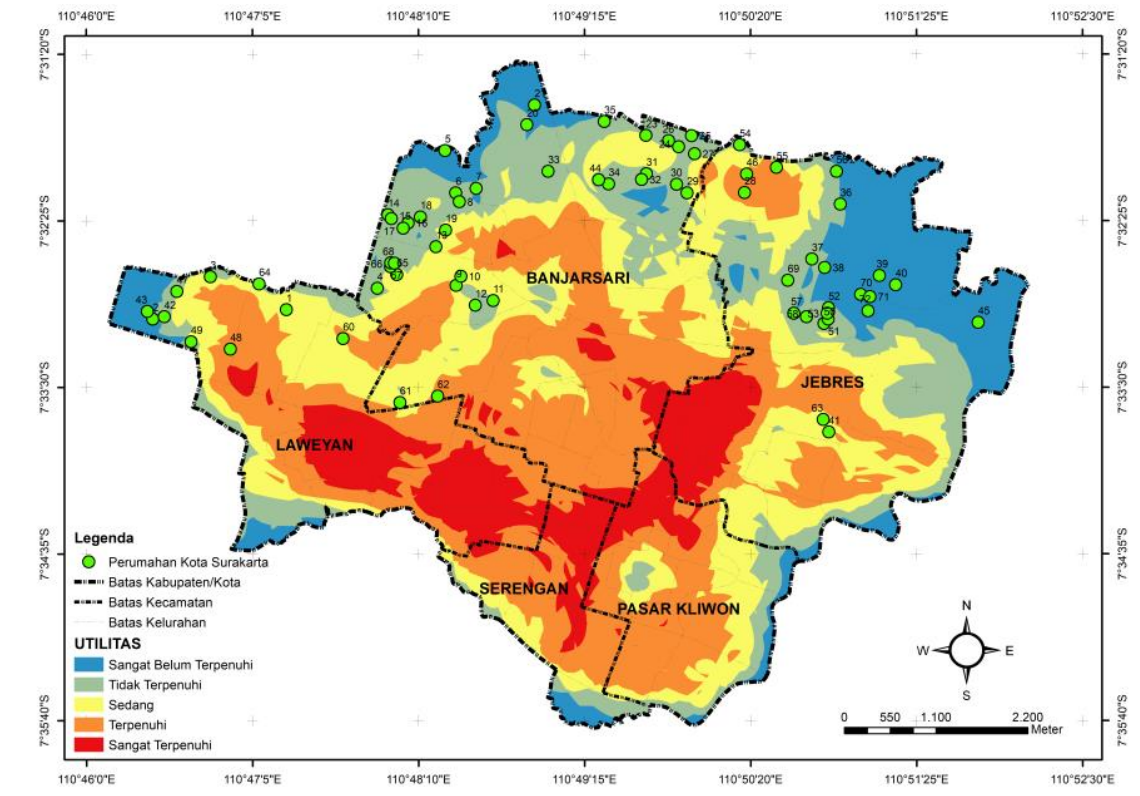

Sumber: Analisis, 2018

Gambar 6. Sebaran Perumahan Terhadap Utilitas

Dari gambar 6 menunjukkan bahwa sebaran perumahan yang dibangun swasta maupun pemerintah cenderung berlokasi di daerah yang belum terpenuhi oleh utilitas publik. Dapat dilihat pada analisis spasial masih ada beberapa perumahan masih sulit dijangkau oleh jaringan utilitas seperti jaringan listrik, jaringan air bersih, jaringan telephone, jaringan air limbah dan jaringan gas. Pada analisis ini masih ditemukan pembangunan sarana utilitas yang terpusat pada wilayah pusat aktivitas saja dibanding wilayah pengembangan perumahan (Laweyan, Banjarsari dan Jebres). Pola sebaran perumahan pada analisis ini cenderung menjauhi utilitas Kota Surakarta dibandingkan terpenuhinya fasilitas jaringan utilitas. Tentunya hal ini berbanding terbalik dengan teori yang dikemukakan oleh Singh bahwa penerapan utilitas adalah pembentuk embrio terciptanya perumahan. Misalnya pada perumahan yang terletak pada Kelurahan Mojosongo di Kecamatan Jebres ada beberapa yang tersaluri jaringan listrik saja hal ini tentunya menjadi temuan dan masukan untuk pemkot dalam pemerataan jaringan utilitas di Kota Surakarta. Hal ini berbanding terbalik pada perumahan yang berada di tengah kota yang terpenuhi akan jaringan utilitas kota misalnya Perumahan Manahan Park View, Perumahan Rakyat Gremet, Perumahan Dinas PT. Pos dan Perumahan Karangasem. Kesimpulan analisis ini bahwa sebaran perumahan yang mengarah di pinggiran kota tidak terkait terhadap jaringan utilitas yang disediakan, temuan lain dari observasi di lapangan bahwa perumahan terlebih dahulu terbangun sebelum adanya jaringan utilitas. Kesimpulan dari temuan ini yakni perlu perencanaan yang matang yang dibarengi dengan memperhatikan kondisi di lapangan.

Dari gambar analisis pola sebaran terhadap 4 aspek di atas, dapat menjadi dasar pola perkembangan perumahan di Kota Surakarta berikutnya. Dengan mengacu dari analisis pola sebaran terhadap 4 aspek 
dapat disimpulkan bahwa karakteristik pola sebaran perumahan di Kota Surakarta mengarah pada lahan kosong dan jauh dari fasilitas publik. Pemilihan lokasi ini dapat diartikan bahwa developer dan pemerintah memilih lokasi dipinggir kota karena harga lahan masih belum terlampau tinggi atau masih terjangkau.

Penelitian ini hanya ingin melihat pola sebaran perumahan yang dibangun oleh pengembang dan pemerintah setempat, dengan menggunakan variabel jarak terdekat perumahan dengan mengacu pada aksesibilitas (jalan) untuk mencapainya dari titik rumah ke titik rumah lainya. Analisis pola sebaran perumahan di Kota Surakarta digunakan analisis tetangga terdekat (nearest neighbour analysis) dengan menghitung Nilai T (indeks penyebaran tetangga terdekat) melalui formula sebagai berikut:

Dimana :

$$
\mathrm{T}=\frac{j \mathrm{u}}{j h}
$$

T : indeks penyebaran tetangga terdekat .

Ju : jarak rata-rata yang diukur antara satu titik dengan titik tetangganya yang terdekat .Nilai ju diperoleh melalui penjumlahan jarak satu titik dengan titik tetangga terdekat sebesar $11,44 \mathrm{~km}$ (detail lihat di Gambar 4.1) dibagi dengan banyaknya jumlah Perumahan (70).

Jh : jarak rata-rata yang diperoleh andaikata semua titik mempunyai pola random $=T=1 /(2 \vee p)$

$\mathrm{P} \quad$ : kepadatan titik dalam tiap $\mathrm{km} 2$ yaitu jumlah titik $(\mathrm{N})$ dibagi dengan

luas wilayah dalam $\mathrm{km2}(A)$, sehingga menjadi $N / A$

$\mathrm{ju}=\left(\sum \mathrm{j}\right) /\left(\sum \mathrm{n}\right)=11,44 / 70=0,16 \mathrm{~km}$

$P=\left(\sum n\right) / L=70 / 46,01=1,5$

jh $=1 /(2 \vee p)=1 /(2 V 1,54)=1,24$

$\mathrm{T}=\mathrm{ju} / \mathrm{jh}=0,16 / 1,24=0,129$

Dari nilai $T$ dinterpretasikan dengan Continum Nearest Neighbour Analysis dalam model yang dikembangkan oleh Hagget, (1970) pada Gambar 7, maka pola sebaran perumahan di Kota Surakarta cenderung berpola mengelompok (clustered), hal ini diindikasikan dengan besarnya nilai T sebesar 0,129 yang cenderung mendekati 0 .

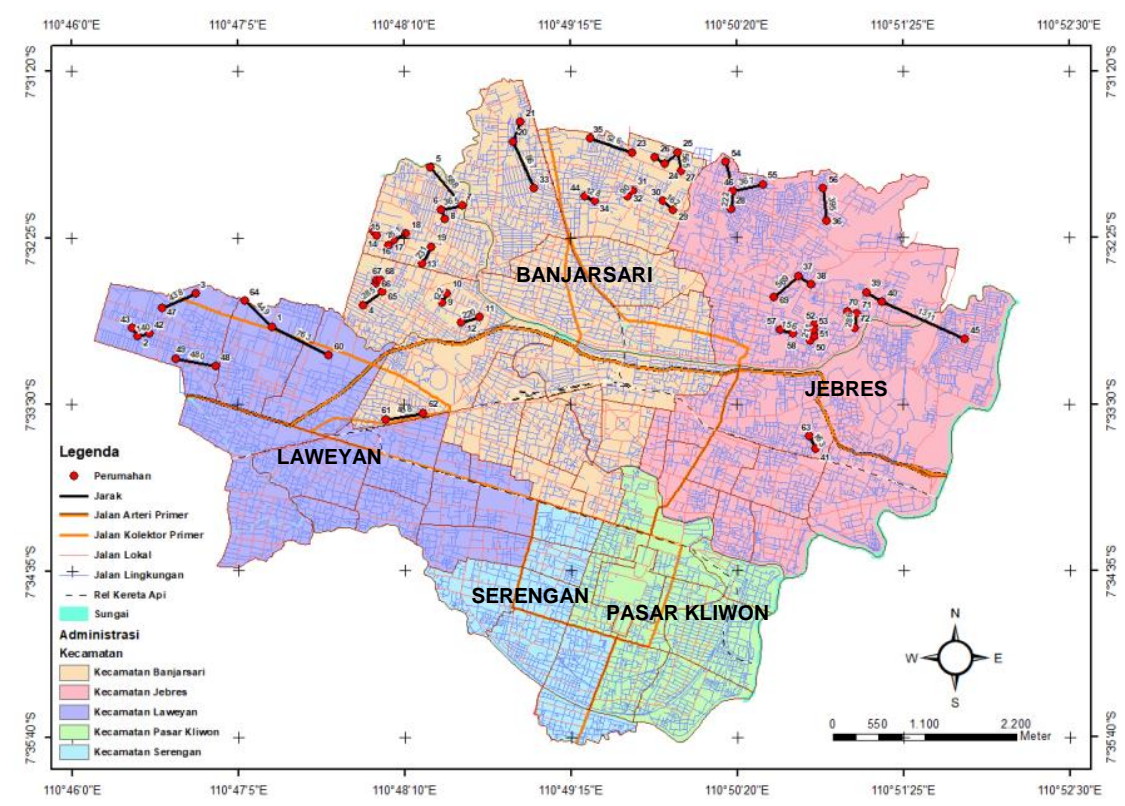

Sumber: Analisis, 2018

Gambar 7. Peta Sebaran Perumahan Di Kota Surakarta

Dari gambar 7 peta sebaran perumahan dapat melihat perumahan yang tersebar di pinggiran 3 kecamatan (Laweyan, Banjarsari, Jebres) terlihat mengelompok. Rata - rata jarak terdekat dari pencapaian satu rumah ke rumah yang lainnya ialah $100 \mathrm{~m}$, sekaligus pola sebaran perumahan dikategorikan pola sebaran perumahan yang mengelompok. Perumahan ini tersebar di Kecamatan Banjarsari (Kelurahan 
Widodo, Sunarti/ Jurnal Pembangunan Wilayah dan Kota, Vol.15 No.4, 2019, 288-300 Doi: https://doi.org/10.14710/pwk.v15i4.21984

Banyuanyar, Kelurahan Kadipiro) dan Kecmatan Jebres (Kelurahan Mojosongo) dengan jarak terdekat yang bervariatif. Terkait penyebaran dengan pola mengelompok dengan jarak yang sangat dekat dipengaruhi oleh beberapa aspek, pertama yaitu aspek kebijakan yang mengarahkan pembangunan di daerah utara yaitu Kecamatan Banjarsari dan Mojosongo yang masih cukup luas diperuntukkan pembangunan perumahan, kedua aspek sosial budaya yang mempengaruhi masyarakat memilih hunian dengan kepadatan sedang atau rendah yaitu berada di pingggiran kota Surakarta, ketiga aspek ekonomi yaitu dimana harga perumahan masih terjangkau oleh masyarakat umum yang berada pada bagian utara dan yang terakhir aspek fisik dimana jaringan jalan sebagai satu - satunya indikator dalam membentuk pola sebaran perumahan di Kota Surakarta. Kesimpulan dari analisis pola sebaran perumahan ini tentunya dapat menjadi rujukan pemerintah setempat untuk mengkaji kembali perencanaan wilayah bagian utara yang dijadikan pengembangan perumahan, dimulai dari membangun fasilitas umum terlebih dahulu dengan melihat arahan sebaran perumahan dan mengaplikasikan kebijakan dengan menerapkan asas pembangunan keberlanjutan di kota Surakarta.

Dalam analisis ini akan mencoba mengaitkan kondisi pola sebaran terhadap pola perkembangan perumahan di Kota Surakarta. Mengacu dari teori perkembangan pola perumahan dan permukiman lebih mengarah pada pola kawasan yang menyebar dari pada pola heterogen. Kecenderungan pola yang mengarah berpola menyebar, dicirikan oleh beberapa faktor, sebagai berikut :

a. Mengacu pada analisis tata guna lahan di Kota Surakarta, terlihat sebaran pola tata guna lahan mengikuti pola menyebar. Ini dapat dilihat dari adanya sebaran fungsi tata guna lahan yang tersebar acak dan sebagian fungsi perumahan mengikuti sistem jaringan jalan dan sebagian menempati kawasan lahan kosong terlebih dahulu, dibandingkan dengan pola yang dipengaruhi oleh jarak dari pusat kegiatan.

b. Jumlah daerah pusat kegiatan lebih ke arah unicentered patteren dibandingkan dengan multicentered pattern. Daerah pusat kegiatan, nampak di sekitar kawasan Gladak sebagai pusat kota. Kawasan ini dekat dengan kawasan keraton, yang secara historis merupakan pusat aktivitas kegiatan pada masa lampu sekaligus menjadi cikal bakal pertumbuhan perumahan dan permukiman di Kota Surakarta.

c. Dari peta tata guna lahan, peta jaringan jalan dan sebaran kepadatan penduduk, nampak adannya gejala sentrifugal ke arah barat kota Surakarta, yang ditunjukkan dengn pola jaringan jalan yang menjari dan perkembngan kawasan permukiman disisi utara kearah barat dan timur. Hal ini disebabkan karena terbatasnya lahan di kawasan selatan dan tingkat kepadatan yang sangat tinggi, serta adannya aksesibilitas sisi barat yang lebih menonjol dibandingkan dengan sisi utara dan timur kota Surakarta yang masih kurang aksesibilitas trasnportasi berbasis massal.

d. Dilihat dari banyaknya fasilitas publik dan utilitas di kota Surakarta, dapat dilihat kesenjangan yang sangat mencolok yaitu terpenuhinya segala kebutuhan di pusat kota sementara didaerah piggiran seperti bagian selatan dan timur belum dikembangkannya fasilitas dan utilitas publik.

e. kepadatan penduduk di kawasan sisi selatan Kota Surakarta, yang dekat dengan pusat kota yang berarti kawasan dihuni sebagan besar perumahan yang sangat padat, karena wilayah ini sangat dekat dengan pusat kegiatan dan daya tarik ekonomi yang sangat kuat (lapangan pekerjaan yang tinggi). Sedangkan kawasan perumahan disisi utara dan barat cenderung dengan kepadatan dan sosial ekonomi yang cenderung stabil

Sebaran perumahan terhadap aspek sarana prasarana terlihat fasilitas di pusat kota sangat terpenuhi dan tingat keterjangkauanya sangat dekat dibanding dengan wilayah dibagian barat dan utara yang dimana dominan menjadi lokasi penelitian. Data ini menunjukan bahwa persebaran perumahan yang dibangun developer dan pemerintah masih banyak yang belum terjangkau oleh fasilitas umum. Fasilitas yang disediakan pemerintah belum tersebar di setiap wilayah kota Surkarta, hanya terfokus pada satu titik dipusat kota. Pada wilayah bagian barat (Kecamatan Laweyan) dapat dilihat ada beberapa perumahan yang dalam jangkuannya masih belum terpenuhi akan fasilitas publik akan tetapi pada kawasan ini masih dalam tahap aksesibilitas trasnportasi yang cukup mendukung untuk menjangkau fasilitas publik. Sedangkan wilayah bagian utara (Kecamatan Banjarsari) dari hasil analisis spasial menunjukan pola sebaran perumahan akan 
saranaprasana juga belum terpenuhi. Begitu juga diwilayah bagian timur (Kecamatan Jebres) masih banyak juga pola perkembangan perumahan yang masih jauh akan kejangkauan fasilitas umum.

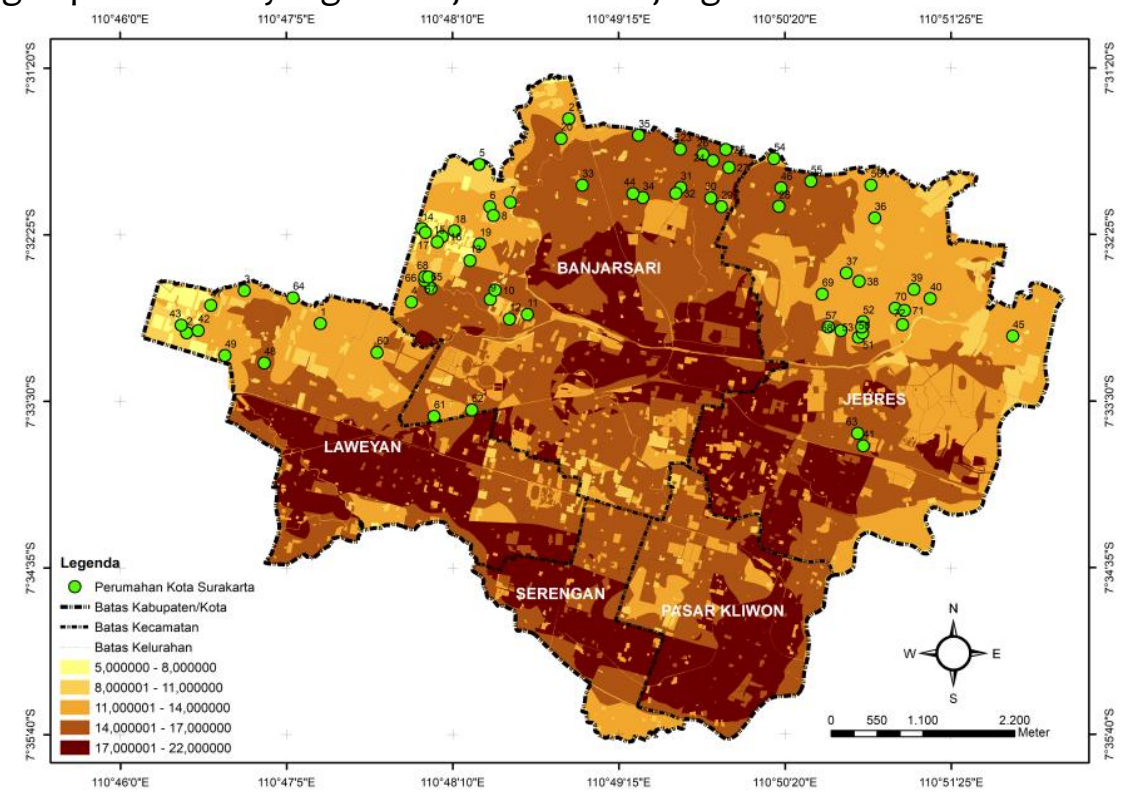

Sumber: Analisis, 2018

Gambar 8. Analisis Pola Perkembangan Perumahan

Dari gambar 8 pola perkembangan perumahan yang tersebar di pinggiran Kota Surakarta terindikasi dengan pola perkembangan radial tidak menerus. Pola ini dapat dilihat dari perkembangan perumahan yang tidak menerus dari kepadatan tinggi sampai ke kepadatan sedang yaitu dari pusat kegiatan ke pinggiran kota. Dari analisis ini dominasi titik penelitian perumahan berada pada kepadatan yang sedang serta status sosial ekonomi yang relatif tidak stabil, hal ini dilihat dari fisik perumahan yang beberapa berada di lingkungan cenderung kumuh. Pola perkembangan perumahan di Kota Surakarta dipengaruhi akan persediaan lahan kosong dan jaringan jalan. Lahan kosong di Kota Surakarta masih menjadi sasaran para pengembang untuk mengubahnya menjadi perumahan. Menurut Zahnd (2007) pola kawasan terbagi menjadi 3 pola yaitu pola kawasan yang homogen, heterogen dan menyebar, sedangkan pola kawasan di Kota Surakarta cenderung dengan pola menyebar dan tidak tertata. Hal ini terlihat bahwa titik perumahan satu dengan yang lainnya tidak terintegrasi dari hal pendistribusian utilitas maupun akomodasi transportasi berbasis massal. Kesimpulan dari analisis ini adalah pola perkembangan perumahan yang dipengaruhi beberapa variabel fisik menggiring pola perumahan berada pada di pinggiran kota Surakarta dengan fasilitas dan utilitas yang kurang memadai. Sementara pengaruh variabel non fisik dipengaruhi oleh kepadatan penduduk yang tinggi di pusat kegiatan dan kebudayaan di Kota Surakarta kemudian bergeser ke pinggiran kota yang cenderung kepadatan sedang dan lahan masih tersedia untuk dibangun perumahan.

\section{KESIMPULAN}

Dari identifikasi pola sebaran yang didasarkan pada analisis tetangga terdekat terhadap sebaran perumahan, ditemukan pola sebaran perumahan Kota Surakarta mengarah atau cenderung membentuk pola sebaran mengelompok, yang diindikasikan dengan nilai T/indeks tetangga terdekat sebesar 0,129. Analisis yang melibatkan 4 aspek antara lain aspek kebijakan yang mengarahkan pembangunan perumahan diarahkan ke bagian utara Kota Surakarta, aspek sosial yang mengindikasikan kepadatan tinggi yang ada dibagian selatan mengarah ke kepadatan rendah ke bagian utara, sementara untuk aspek ekonomi mengidentifikasikan harga lahan yang masih relatif terjangkau pada bagian utara Kota Surakarta, dan yang terakhir adalah aspek fisik dimana menjadi faktor penting dalam pengembangan suatu kawasan akan teteapi dalam kasus penelitain ini masih minimnya fasilitas serta sarana prasarana menjadikan pola persebaran perumahan belum merata. Temuan dari beberapa aspek dalam mempengaruhi pola sebaran kota di Kota 
Surakarta mengarah pada pola linier menerus di pinggiran Kota Surakarta mengikuti perkembangan jalan, harga lahan yang masih terjangkau, kepadatan penduduk yang masih rendah dan tersediannya lahan kosong. Indikasi ini dapat dilihat di wilayah bagian barat, timur dan utara (Laweyan, Jebres dan Banjarsari) yang tumbuh kembang perumahan sangat pesat di pinggir Kota Surakarta. Pola sebaran yang mengarah lebih digerakkan oleh elemen lahan dan jaringan jalan dari pada tersedianya fasilitas umum yang tersedia. Temuan ini tentunya dapat membuat masukkan buat pemerintah dan developer untuk bekerjasama dalam merencanakan fasilitas dan utilitas untuk menunjang perkembangan perumahan.

\section{PERNYATAAN RESMI}

Terimakasih kepada kedua orang tua yang telah membiayai penelitian ini, staf pengajar Magister Perencanaan Wilayah dan Kota serta Bapppeda yang menunjang kebutuhan data sehingga sampai menghantarkan pada gelar Magister Perencanaan Wilayah Dan Kota.

\section{REFERENSI}

Adisasmita, R. (2015). Teori Pertumbuhan Kota. Yogyakarta: Graha Ilm.

Chapin, Jr, F. Stuart and Edward Kaiser. (1995). Urban Land Use and Planning. Fourth Edition. Illinois: University of Illinois Press.

Deurloo \& Musterd. (2001). Residential Profiles of Surinamese and Moroccans in Amsterdam. Urban Studies, Vol 38, No 3 .

Giyarsih, Sri Rum (2015). Analisis Fragmentasi Spasial Berbasis Citra Multitemporal Untuk Mengidentifikasi Fenomena Urban Sprawl Di Surakarta. Jurnal Perencanaan Wilayah dan Kota, Volume 12.

Hagget, Peter (1975). Nearest Neighbor Analysis. Inggris: University of Bristol.

Issahaka Fuseini and Jaco Kemp (2016). Characterising urban growth in Tamale, Ghana: An analysis of urban governance response in infrastructure and service provision.

Jayadinata, T. Johara (1999). Tata Guna Tanah dalam Perencanaan Pedesaan Perkotaan dan Wilayah. Institut Teknologi Bandung.

Koestoer, R. H. dkk., ed. (2001). Dimensi Keruangan Kota: Teori dan Kasus. Jakarta: UI Press.

Mirkatouli, J., Samadi, R., \& Hosseini, A. (2018). Evaluating and analysis of socio-economic variables on land and housing prices in Mashhad, Iran. Sustainable Cities and Society, 41(June), 695-705. https://doi.org/10.1016/j.scs.2018.06.022.

Miro, F. (2005). Perencanaan Transportasi untuk Mahasiswa, Perencana, dan Praktisi. Erlangga. Jakarta.

Moughtin Cliff (1992). Urban Design Street and Square, Department of Architecture and Planning University of Nottingham, Great Britain.

Setioko, B. (2013). Konsep Kearifan Lokal Pada Pertumbuhan Kawasan Pinggiran Kota, 13, 89-94.

Singh, N., K. S. Sandhu, and M. Kaur. (2005). Physicochemical properties including granular morphology, amylose content, swelling and solubility, thermal and pasting properties of starches from normal, waxy, high amylose and sugary corn. Progress in Food Biopolymer Research. 1: 43- 55. http://www.ppti.usm.my/pfbr.

Soeratno (2015). Perkembangan Spasial Penggunaan Lahan Real Estat Dan Pengaruhnya Terhadap Perekonomian Kota Surakarta. University Research Coloquium

Sunarti, Yuliastuti. N dan Indriastjario. (2018). Kolaborasi Stakeholder Dalam Penyediaan Perumahan Untuk Masyarakat Berpenghasilan Rendah Di Kota Salatiga. Jurnal Tata Loka : Planologi UNDIP, 20, 455-471.

Tukiran. (2002). Mobilitas Penduduk Indonesia: Tinjauan Lintas Disiplin. UGM : Pusat Studi Kependudukan dan Kebijakan.

Wahyu, M., \& Moch, R. (2014). Geo Image ( Spatial-Ecological-Regional ) Perkembangan Permukiman Di Kecamatan Gajah Mungkur, 3(2), 1-8.

Yoelianto. (2005). Kajian Perkembangan Spasial Kota Purwodadi. Semarang. Perpustakaan MPWK Undip.

Yuuwono A.B, (2007). Pengaruh Orientasi Bangunan Terhadap Kemampuan Menahan Panas Pada Rumah Tinggal Di Perumahan Wonorejo Surakarta. Magister Teknik Arsitektur : Universitas Diponegoro Semarang 